\title{
Ebola research fueled by bioterrorism threat
}

A $s$ the world struggles to respond to the growing Ebola outbreak in Africa, the discussions of new vaccines and treatments have centred overwhelmingly on questions related to the ethics and efficacy of their use.

But why was Ebola virus disease being researched at all, given its relatively low incidence? Since being documented and named in 1976, the virus has infected about 2400 people and killed fewer than 1600.

The answer is that following the 2001 suicide terrorist attacks on New York City's World Trade Center, fear grew that Ebola could be turned into a bio-weapon, and an increase in research funding followed. There are now 10 or so vaccines and treatments in various stages of research, development and clinical testing.

"Were there not a perceived need to protect against an Ebola outbreak being spread around the world as a bioterrorist weapon, I don't think anyone would be where we are now," says John Eldridge, chief scientific officer with Profectus BioSciences, a US company whose anti-Ebola rVSV vaccine is on the fast track for human use.

"Biodefense has been absolutely catalytic in Ebola prevention develop- ment," agrees Matthew Watson, a senior analyst at the UPMC Center for Health Security in Baltimore, which does a regular update on US biodefence initiatives. "If public health need was the absolute driver, we would be absolutely nowhere because frankly not too many people were getting sick with Ebola, particularly when we compared it to other public health concerns."

The threat that exotic, deadly diseases could be weaponized brought about "intense product development efforts," agrees Michael Kurilla, director of the Office of Biodefense Research Affairs at the US National Institutes of Health. The result of these efforts is what Kurilla typifies as an "embarrassment of riches" where government and companies are forced to decide which of the leading anti-Ebola drugs can be actively pushed forward.

All of which raises the question of whether there is any evidence that Ebola actually could be weaponized. An intriguing finding was reported by the National Microbiology Laboratory in Winnipeg in a November 2012 article in Scientific Reports. When pigs were infected with the Ebola virus and placed in a room with macaque monkeys, the monkeys got sick even though there was no contact with

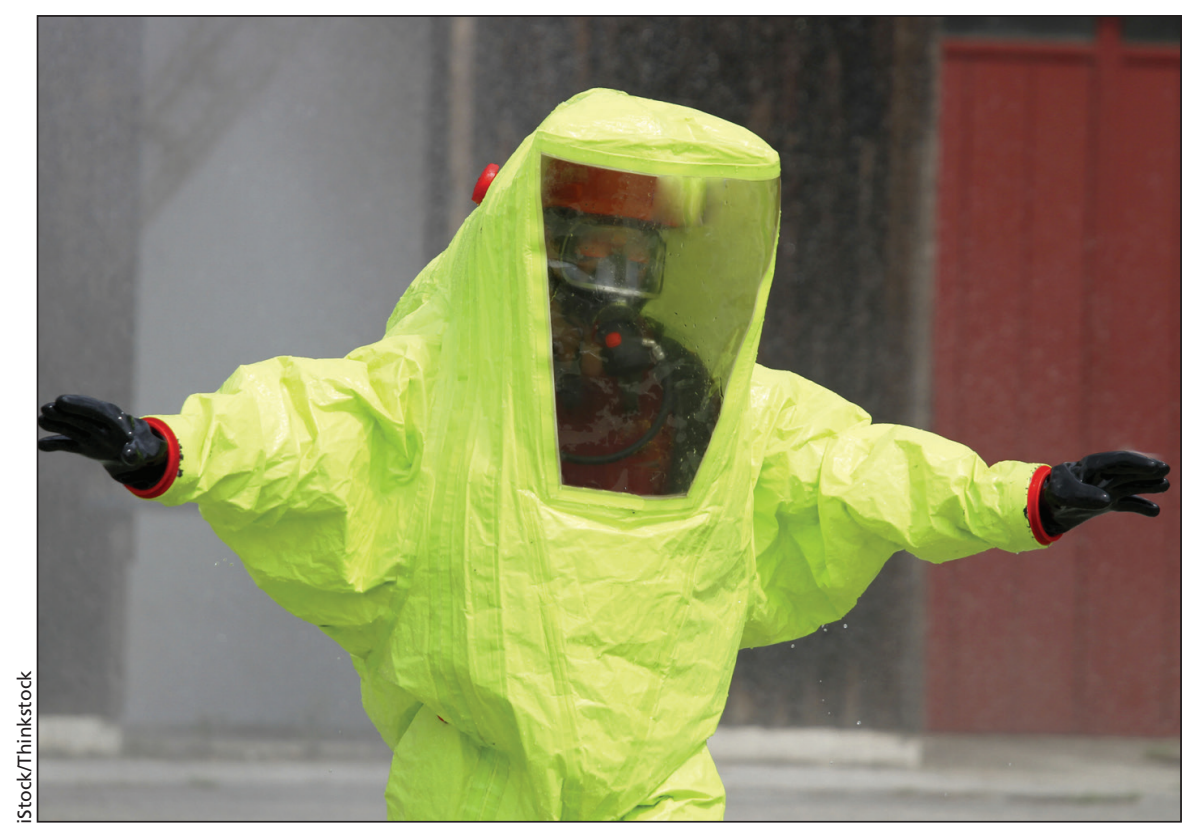

The possibility that Ebola could be used as a bioterrorist weapon is remote, but fears have nonetheless fueled research. blood, tears, sweat or other nonairborne vectors previously believed necessary to spread the disease.

Does this mean Ebola's airborne weaponization is likely? Kurilla says he can't say it will never happen, but given intrinsic differences in Ebola's operation in different species, "it is probably unlikely."

Research driven by biothreat fears continues nonetheless. Since 2001, the US has spent nearly $\$ 79$ billion on biodefence-related programs. A substantial portion of this has gone into projects with general applications, such as preparing US hospitals for dealing with a massive influx of sick patients; however, the US Departments of Defense, Homeland Security, and Health and Human Services, as well as other agencies, have spent about a third - $\$ 26$ billion — on biologyspecific research.

Watson says "it is not clear how much money has specifically gone into developing Ebola drugs and vaccines alone." However, quite substantial numbers pop out when private companies present their business models to potential investors. Tekmira Pharmaceuticals Corp., for example, has received $\$ 140$ million from the US Department of Defense, and the company notes in a press release that, although the drug might be used for the current outbreak in Africa, its contracted purpose is to facilitate "the advanced development and acquisition of medical countermeasures and systems to enhance biodefense response capability."

Americans are not alone in funding biodefence research related to Ebola. The Canadian Department of National Defence invested \$7 million in developing an Ebola vaccine at the National Microbiology Laboratory. This is the vaccine that the federal government donated to Africa in August.

On Sept. 24, the US government released its policy on biological research that could be used for terrorism or other nefarious purposes. Ebola is on the list. - Stephen Strauss, Toronto, Ont. 